\title{
Doing God's Work: The Missonary's Task of Translation or Who Makes the Best Jesuits: Comparatists, World Literature Scholars, or Real Jesuits?
}

\section{DOROTHY FIGUEIRA}

\begin{abstract}
This paper takes as its point of departure the sixteenth-century Jesuit construction of Confucianism and the manufacture of the figure of Confucius in the form of translations of the Chinese classics. In examining the Jesuit policy of accommodation in Asia, I ask whether we might not view these efforts as precursors for the tasks we seek to perform as Comparatists and World Literature scholars. Like the Jesuits in China who sought to package Confucius, we seek to package the world by contextualizing form and argument, canonizing a body of work, producing creative readings sand projecting a vision onto the foreign Other. I focus in particular on the work of Matteo Ricci and his catechism, the Tianzhu shiyi, as a work of cultural mistranslation. I ask to what degree are our current critical readings of the Other not also failures. I question the purposes for which one "misreads".
\end{abstract}

Kewords: Jesuits; Confucius; Comparative Literature; World Literature; Matteo Ricci; China and India missions

Scholars have fully examined the manner in which the Jesuits created the role of Confucius as the bearer of Chinese significance, that is to say, how Confucius became a fictionalized European exemplar of reason and civility. ${ }^{1}$ It is now generally accepted by historians that the construction of a persona known as Confucius was not what the ancient Chinese knew as the historical figure of Kongzi. As Lionel Jensen has shown in his book Manufacturing Confucianism (1997), Confucius was in part fashioned by the West. Inspired by the figure of Kongzi and drawing upon a one thousand-year-long transmission of indigenous texts about him, sixteenth-century Jesuit fathers fabricated someone they called Confucius. It was this construction in the form of translations of the Chinese classics that was then transported back to Europe and would influence the works of thinkers such as Voltaire, Rousseau,

1 See Hsia, Meynard, Mungello, Rubies among others.

DOI: http://dx.doi.org/10.12697/IL.2016.21.1.2 
Doing God's Work

Montesquieu, Comte, Quesnay, Fontenelle, Diderot, Leibniz, Malebranche and Bayle.

In the following paper, I will investigate how the Jesuits' attempts to take their mission to Asia and immerse themselves in Asian religion manifested itself in a process of "going native" in order to aid in conversions. This process presupposed that the Asian Other could be perceived as equal to the European both intellectually and morally. The accommodation policy adopted by the Jesuits consisted of seeking out a common experience, locating lines of filiation, and working out acceptable compromises. Toward this end, they embarked on a massive effort of translation. I wish to look at this Jesuit policy as prefiguring our common labor of comparing cultures - especially through Comparative Literature's attempts to contextualize form and argument and its openness to hermeneutical play and dialogue. Can we envision the Jesuits' encounter with Asia (with all its imperfections) as a metaphor for our task as comparatists, translators or World Literature scholars? They all seem to engage in the common tasks of canonizing a body of work, producing "creative" readings, and projecting a vision onto the foreign Other. There even seems to be, at least among the Jesuits and World Literature scholars, a missionary zeal at work in their endeavors. However, before setting out to examine whether the Jesuits were proto-comparatists, let us first look at what the Jesuits were actually doing in Asia, how it differed from what they were seeking in China, and how this encounter was structured by the translations of Matteo Ricci.

Francis Xavier (1506-52) arrived in India in 1542. His letters speak of his admiration for the poor coastal Indians to whom he preached. His respect for low-caste fishermen stood in sharp contrast to the contempt he felt for Indian high castes. Xavier saw brahmins as the main support of paganism. According to the future saint, they were the most perverse people in the world (letters $\# 20,90,96,97,110$ in Xavier 1944-1945) and the greatest threat to the proselytizing mission (Schurhammer 1977: 408). Xavier encountered other problems with the fledging Indian mission. He discovered that when Hindus converted, they tended not to abandon their former religious practices. They wanted to enjoy whatever benefits Christianity could afford them as well as those assured them as caste Hindus. Xavier soon realized that under these conditions it would be very difficult to man and maintain the missions with Indian Christians alone and, due to the Reformation, re-enforcements from Europe were not plentiful. From the point of view of the Church, it became quickly clear that Indian caste pride presented an insurmountable problem in converting Indians. The fierce dedication of the Indian population, both Hindu and converted, to caste prejudice not only had consequences for the long-term success of the Indian mission. It forced the Jesuits to turn their 
attention to other more fruitful venues. Most importantly, it encouraged a comparative perspective on Asia. The quality and customs of India would henceforth be viewed in relation to those of Japan and China. In such a comparison, Xavier found the Japanese and Chinese to be far more rational than the Indians and, as a consequence, better prepared to abandon idolatry and accept the salvation of the Catholic Church. He also viewed them as white and, therefore, more civilized. Proselytizing the Japanese and the Chinese was deemed a better use of time and personnel. What is important here to note is that, at this very early stage of East-West encounter, even before fully known, Japanese and Chinese figured higher than other infidels (Jews and Moslems included) in a hierarchy of peoples. The contest, initiated by Xavier, of unfavorably comparing India to other possible Asian sites for missionary favor would play itself out in the work of Alessandro Valignano (1531-1606) and Matteo Ricci (1552-1610).

Valignano was appointed the Visitor to the East in 1574 . He would serve 6 years in India (1583-87; 1595-97), 12 years in Japan (1571-82; 1590-92; $1598-1603$ ) and 5 years in China (Macao 1588-90; 1603-6). As an Italian aristocrat, Valignano was impressed by what he perceived as the noble and civilized behavior of the Japanese and Chinese. Like Xavier, he too did not judge Indian brahmins favorably, especially when he compared them to Japanese nobility. But, even before he set sail to the East, Valignano had already developed clear racial prejudices regarding the peoples he would encounter. Valignano felt that black Africans were truly barbarians with no capacity for Christian teaching. They lived in sloth and ignorance (Lach 1965: 259). Indians only rated slightly higher in his estimation. They too were born to serve (Schütte 1980: 1.131). He judged Indians vile and low (Valignano 1944:28) and extraordinarily untruthful (Schütte 1980: 1.132. He characterized them as naked, commonly poor, miserable, mean, and servile (Valignano 1944: 24) Both Africans and Indians were of a lower nature than Europeans and white people (Rubies 2000: 7), among whom Valignano also counted the Japanese (Valignano 1944: 111) and the Chinese. The former he held in contempt, the latter he held in great regard. Valignano's initial prejudices did not diminish upon arriving in the East. $\mathrm{He}$ felt that the Japanese and the Chinese, in addition to being white (or maybe because they were deemed white) possessed a sophisticated culture and were capable of rational behavior. For Valignano, there were two races: the blacks, consisting of the Africans and the Indians, and the whites, consisting of Europeans, the Japanese and the Chinese. As opposed to the Jesuit policy with India, Valignano felt he could make the case for Japanese and Chinese exceptionalism. He, therefore, encouraged the study of the Japanese and 
Chinese languages and the adaptation of their customs. In this format, accommodation involved a form of cultural assimilation and enculturation. In the case of China, it entailed "becoming Chinese" or what anthropologists would term "sinification." The cornerstone of this accommodation policy was to have the Jesuit missionaries do all things in the local manner with regards to language, dress, food, politeness, and cleanliness. This process was ultimately stymied in Japan for political reasons that extend beyond the scope of this study. Suffice it to say that the Jesuits were expelled from Japan in 1587 and those who did not leave were martyred along with their Japanese converts under the $3^{\text {rd }}$ Tokugawa Shogun who then closed down Japan to the outside world for the next 200 years. Valignano arrived in China the year following this expulsion from Japan.

Between 1583 and 1595, the Jesuits carved a niche in China as Buddhist monks. Matteo Ricci was initially impressed with Buddhism. He and his colleague Michele Ruggieri adopted the identity of osciani (or Buddhist monks) and essentially ceased functioning as Catholic priests. They took on the clothing of Buddhist priests because they initially saw Buddhist monasticism as a vehicle for becoming Chinese (Tacchi Venturi 191113: 2.72). Ricci was impressed by Buddhism because he felt it resembled Christianity in many respects - both were foreign to China; both demanded celibacy, structured a formal priesthood, and believed in the afterlife, charity, compassion, and the suppression of passions. Ricci was also taken with what he thought to be the Buddhist ascetic lifestyle. Quite quickly, however, he realized that because Buddhism was not indigenous to China and not publically appreciated by well-placed Chinese; its followers lacked social status. To obtain such a position in Chinese society, Ricci sought legitimacy in a return to what he understood as the pure teaching of the ancients. We have noted the Jesuits' poor opinion of India and all things Indian. Since Buddhism originated in India, it was necessarily corrupt. It also had to be rejected because of other foreign elements. Ricci was seeking a truly Chinese religion with which to work. What would be constructed as Confucianism became that religion. It is worth signaling, however, that this manufacturing of Confucius and Confucianism as well as Ricci's attraction to it owed much of its impetus to the earlier negative assessment of India made by Xavier and Valignano. In 1575, Ricci decided to embrace la legge de'letterati. He and Ruggieri jettisoned their Buddhist trappings for robes of the letterati and began calling themselves $r u$ (Tacchi Venturi 2.1911-13: 2.136-7). Buddhism (along with Daoism) was henceforth deemed heretical. Both philosophies were (perhaps) not sufficiently Other for Ricci and Ruggieri. What is certain is that Ricci and Ruggieri needed the prestige the letterati afforded because 
FIGUEIRA

they now understood that to be a foreigner and a Buddhist priest in China was considered vile (Tacchi Venturi 1911-13: 2.104).

This transformation was Ricci's second accommodationist strategy and for a period of time it met with moderate success. The problem with the adoption of the $r u$ was that, while it designated descent from Kongzi, it also meant so much more: the veneration of the imperial cult, rituals of legitimacy, examination candidates, scholar-officials, sodalities of meditation and worship, ancestor worship, and state doctrines. To avoid such complications, Ricci did something quite radical: he reduced the $r u$ to a single symbol and designated it "Confucian." In other words, he created a Christianized ru doctrine that advocated the resurrection of some supposed "true teaching" of Kongzi in the spirit of restorationism. Under Ricci's translational efforts, the $r u$ was thus interpreted or read as the original teaching of Confucius, who was now viewed as the cultural backbone of Chinese civilization.

What is of interest to us as literary scholars is that the Jesuit process of accommodation paralleled many of the tasks we regularly perform as translators and comparatists. First and foremost, their work necessitated a canon formation and the privileging of certain texts. The Jesuits selected a number of Chinese texts, deemed representative or sufficiently malleable for this purpose. They then translated them, and organized them into a system of relations with other (Western) texts dear to them. Toward this end, they translated and wrote exegeses of the Four Books and placed them alongside Plato, Aristotle, Euclid, Ptolemy, the Bible, the New Testament, Augustine's City of God, Aquinas's Summa Theologica and St. Ignatius's Spiritual Exercises. Translation, comparison and critical assessment are tasks we too perform.

Another key element of the Jesuit accommodation policy was the composition of the aforementioned catechisms. From the time of Xavier, the Jesuits in Asia had written catechisms presenting Christianity through rational arguments and biblical narratives, intertwining philosophical arguments on Christian history, the story of Creation, the Fall of Man, and Redemption. These catechisms functioned as a tool for conversions; they were an essential part of instruction and deemed necessary prior to baptism. The genre of the catechism flourished in the medieval period as a prelude to confession. In the Reformation and Counter-Reformation, catechisms took on a renewed purpose in the battle for souls. Luther and Calvin had contributed to the genre, but the Jesuits were particularly skilled at writing them. Here too, are our theoretical tomes so dissimilar from catechisms? Do they both not seek to convert to some perspective. Certainly, anyone who studied in the US in the heyday of deconstruction remembers how literary theory can be treated as a religion. Let's look more closely at Ricci's catechism. 
The Tianzhu shiyi, or The Real Significance of the Heavenly Master appeared in 1603. ${ }^{2}$ This catechism, however, refuted Buddhism with wisdom culled from translations of what were identified as "Confucian" classics, especially the Four Books. In order to succeed as a catechist, Ricci had to reproduce the habitus (to use Bourdieu's term) of the $16^{\text {th }}$ century ru. He had to succeed in cultural crossing. In order to achieve this end, Ricci depicted the Chinese scholar in his dialogue as utterly convinced by the reasoned arguments of the catechism's European priest. Since the disputation was a practice dear to the Chinese, Ricci's catechism takes the form of a disputation. Ricci chose to highlight it even at the expense of presenting a clear exposition of the parameters of the debate. Ricci's narrative focused instead on having his fictional Western scholar gradually awaken in his iconic Chinese interlocutor recognition of the truth to be found in a now obscured ancient Chinese national religion. Of course, a detailed analysis of this dialogue shows the degree to which Ricci's catechism misrepresented this Chinese Urreligion. He presents it as expounding the fundamental Christian concepts of Heaven and Hell, a Supreme Being, just reward, the immortality of the soul and God's creation of all things. Ricci also superimposed a personal God on the impersonal "supreme Heaven" venerated by Confucians. Using analogies from Thomas Aquinas and Aristotelian theories of causation, Ricci attributed claims for a creator God to Chinese concerns with ancestor worship. Ricci also held to the insistence of a pure and original body of doctrine in the context of a belief system. Moreover, he presented Christianity without mention of the Crucifixion, the Last Supper and, hence, the Eucharist.

Although Ricci's catechism was popular with numerous printings, the Chinese very early on recognized how he had obscured fundamental teachings of Christianity (not to mention what Ricci had done to Chinese religious philosophy). They saw through Ricci's denigration of Buddhism and his omission of Christ's ignominious death. Ricci's strategy backfired - it was essentially only a short-term ploy that caused confusion and accusations of deceit. But what I find so fascinating in this episode of encounter is what it has to say to us today. Certainly, Ricci's catechism represents an instance of cultural mistranslation. In fact, he offered us a "dialogue of misapprehension" (Zurcher 1962: 6-7, cited in Yu Liu 2008: 484). It was a brilliant strategy of proselytizing by paying homage, in what could then be grasped by a Westerner,

2 As Thierry Meynard (2013) and others (Standaert 2009: 61-4; App 2012) have shown, Ricci's catechism is structurally very similar to Valignano's Japanese catechism. Meynard has documented how Ricci used the exact same arguments that Valignano had used in Japan to refute the Buddhists in China (Meynard 2013: 307). 
FIGUEIRA

to China's antiquity and seeking to meld it with contemporary reality for Ricci's pragmatic ends (Mungello 1985: 18). The French Sinologist Jacques Gernet has viewed Ricci's alliance with Confucianism as an enterprise of seduction (Gernet 1985: 15, cited in Liu 2008: 471). However, since Ricci's endeavor did not really work, it is hard to accept Gernet's claim as to its deceptive efficacy. I think we can view Ricci's catechism as rather a "magnificent failure" (Gregory 2003: 38, cited in Liu 2008: 487). This brings me to a more speculative conjecture: how much are our readings of the Other not also at times magnificent failures, even if less consciously framed as such. In fact, I am tempted to view Ricci's literary attempt to "read Confucius" as essentially no different from many of our comparative readings.

Jesuit orientalism was crucial for its transformations of a fledgling order of ascetics into the trusted advisors to royalty and the respected technicians of local knowledge (Jensen 1995: 113). The Jesuits became knowledge brokers in the true sense of the term. They contributed to the political and economic shape of the new nations formed after the Peace of Westphalia in 1645. With their authority (through translations) as bearers of wisdom from China, the Jesuits insinuated Confucianism into the plural stream of European selfconsciousness. Their work thus contributed to the evolution of European intellectual debates (Rubies 2005: 244) and greatly impressed the monarchs of Europe, like Friedrich Wilhelm, the Elector of Prussia and Louis XIV and scientists like Leibniz and Newton. As noted, the Jesuits' attempt to "go native" impacted upon the larger Enlightenment project of Humanität. Moreover, I believe that their methods can be seen to resonate in the modern scholarship that many comparatists engage in today.

We enter into all readings with a series of prejudices, what Gadamer terms our wirkungsgeschichtliches Bewusstsein or effective historical consciousness (Gadamer 1962). They sometimes take the form of preconceived notions of what we all find in texts - recent popular "prejudices" include hegemonic violence, sexism and racism. Rarely do we allow ourselves to be dissuaded by what we actually read. We too intentionally distort texts for ideological reasons - the religion of our times. And the texts to which we do such disservices are usually not as obscure as the Chinese texts Ricci sought to read and translate with his initially rudimentary skills. Besides, Ricci was on a mission from God in his "misreadings." What is our excuse? There is something I find noteworthy here (as a comparatist and not a sinologist): Ricci is to be credited with having introduced the notion of cultural commensurability into his comparison of Confucianism with Christianity. And in doing so, he championed the notion of "cultural dialogue," even if his motives were calculated. Once again, I note, sometimes we too engage in calculated 
readings. Let me conclude today by comparing, in broad strokes, what the Jesuits did in China with what we do as comparatists and then with what World Literature theorists would have us do.

Comparatists read comparatively because it is simply more interesting. Reading a text from one tradition and comparing it to something else from another culture is believed to give a fuller and more complete understanding. In their policy of accommodation, seeking formal and informal common points of reference between the texts of one religion and those of Christianity and drawing useful analogies, the Jesuits functioned as proto-comparatists. Like comparatists, they too sought to engage the target culture hermeneutically and through a focus on language. Their engagement was to work with the language of the target culture in order to make sense of the meaning behind the texts. Here to, they appear as precursors of Comparative Literature and its focus on working in the original languages, as opposed to proponents of World Literature who depend on translation. Just as in Comparative Literature, working in the original language allowed the Jesuits to study the texts in question in their wide context, rather than the partial and a-contextualized form that one might find in a World Literature anthology. The Jesuit, the comparatist, and the World Literature scholar are all involved in canon formation. In the case of World Literature, we have what might be seen as a passive canon; representative texts that are deemed "classics" with serious problems arising from considerations of genre and the different cultural notions of what even comprises "literature." The Jesuits - in their quests for texts malleable to suit their needs - and comparatists work with a much more open canon, an active canon, where issues of "representativeness," genre, status as "literature," length, etc. are not as significant.

As I noted, the Jesuits were on a mission from God and we comparatists, at times (particularly when dogmatic theories have reigned), have been known to deify beloved critics, worship before a pantheon of theoretical gods, and pay obeisance to the theory's omnipotence. [I am thinking here of my stint at Cornell University in the height of the deconstruction frenzy of the late 80's.] Comparatists have been known to worship paltry theoretical gods and bring to their teaching and writing rituals a missionary fervor. World Literature also voices a clear messianic zeal in its pretension to "welcome the other" in ways that Comparative Literature supposedly cannot. What could be more messianic than World Literature's overinflated claims to engage in a democratizing process as opposed to Comparative Literature's purported elitism in demanding knowledge of foreign languages? The Jesuits started us on our path to comparing with their attempts to grasp the intellectual history and contextualize the Other through the act of contrasting it to other Others. 
It was only through their experiences in India, that they sought to decipher what was Japanese or Chinese culture. Their (and our) method of comparing involves more than World Literature's attempts to evoke and represent the Other through a partial exploration.

They were, of course, engaged in an imperialist project of converting the world to the true faith. But how different (at least in terms of its overarching project, if not certainly in terms of real power) are they from the World Literature scholar who wants the world to be read, consumed and marketed in English , the academic language of hegemony? How "imperialistic" is it that World Literature purports to redraw boundaries, speak for a supposedly voiceless and (selectively) underrepresented world? Just as the Jesuits sought to package Confucianism, so too does World Literature package the world, by defining the canon, creating categories, and homogenizing their vision. But, Comparative Literature, as a discipline is too open, too diffuse, and nondogmatic, to attempt any similar task. In their framing of the encounter in the local language, both comparatists and Jesuits seek, in albeit a flawed and incomplete manner, a form of engagement that I simply do not see in World Literature, where the encounter depends on the translator's framing within the hegemonic language of English and Western schools of theory. I cannot get past the idea that in World Literature, the Anglophone anthologizer speaks for the non-Anglophone author, and it is only in English that the non-Anglophone text of an often non-White author gains legitimacy and recognition.

Then, there is the simple problem of distortion. The Jesuits engaged is a clear ideological and religious distortion of the texts they translated as tools for conversion. Comparatists engage in distortion to the degree that translating and theoretical readings can distort. But the problems of distortion due to translation are more pronounced for the World Literature scholar because of the degree to which he/she depends on translation. With World Literature, one cannot avoid the problem of translation, how a text becomes different, something commensurate in the target language. Translation changes the Other; there is an implicit claim in translation to improve on the original. Translations involve more interpretation than any engagement with a text in its source language and culture; it imposes a greater distance. With the translating involved in World Literature, there is considerable assimilation, with domestication involved. The Jesuits clearly sought to assimilate the Other as their open strategy of conversion. Just as the Jesuits sought to impose the Church's authority on the native populations they encountered, World Literature also imposes a limited authority. In its claims to dismantle the canon, it too is rather hierarchical and ideological, particularly in the presumption of its practitioners to identify with (by giving voice to) and 
market "marginal" populations. Just as the Church sought to co-opt the margin, so do the critics of World Literature, situated in the cosmopolitan center, co-opt the margins. Just as the Church seeks to liberate the oppressed, so does the World Literature practitioner free (by marketing them in English) oppressed and submerged identities. Just as the Church's hegemony should not be challenged, so too should the World Literature's Amer-Euro-centric definitions of knowledge not face challenge when it embraces linguistic limitations. Comparatively, comparatists seem rather objective.

Given this schema of parallels that I have set up here for us today, how much more important is it to note that Ricci stepped back from the Church's framework of error that posited the debate in terms of idolatry and atheism as opposed to true philosophy. Ricci worked instead within the framework of the hermeneutical tradition of China (Meynard 2013: 320). In Japan, the Jesuits had condemned the moral systems and practices and tried to substitute them with the normative morality of Christianity. Ricci, however, presented Christian morality in relation to a construction of Confucianism by setting it in relation to ancient Chinese texts and their supposed ancient interpretation. Ricci's catechism contextualized form and argument. It attempted to show appreciation for a foreign culture. But more significantly, it exhibited an openness to hermeneutical play, to dialogue (albeit contrived) and offered a model (albeit flawed) for us in our comparatist endeavors today. Like the modern theorist, Ricci canonized a body of work, he offered creative readings, he projected onto the foreign Other traits he desired and sought to cultivate in himself. In this respect, Ricci was not very different from what we do in Comparative Literature. But, when we try to engage the Other, whether as Comparatists or World Literature scholars, we should always ask ourselves to what extent are we not also trying to convert in order to validate our mission?

\author{
Dorothy Figueira \\ figueira@uga.edu \\ University of Georgia \\ 121 Joseph Brown Hall \\ Athens, Georgia 30602-6204 \\ USA
}


FIGUEIRA

\section{Works Cited}

Certeau, M. de. 1975. L'écriture de l'histoire. Paris: Gallimard.

Certeau, M. de. 1988. The Writing of History. Trans. Tom Conley. New York: Columbia UP.

Gadamer, H.-G. 1962. Truth and Method. Tübingen: Mohr.

Gernet, J. 1985. China and the Christian Impact: A Conflict of Cultures. Trans. Janet Lloyd. Chicago: U of Chicago P.

Gregory, J. S. 2003. The West and China since 1500. New York: Palgrave.

Hsia, R. P.-C. 2010. A Jesuit in the Forbidden City. Oxford: OUP.

Jensen, L. M. 1995. Manufacturing Confucianism: Chinese Traditions and Universal Civilization. Durham, NC: Duke UP.

Lach, D. 1965. Asia in the Making of Europe. Chicago: U of Chicago P.

Liu, Yu. 2008. "The Intricacies of Accomodation: The Proselytizing Strategies of Matteo Ricci." - Journal of World History 19.4, 465-487.

Meynard, T. 2013. "The Overlooked Connection between Ricci's Tianzhu shiyi and Valignano's Catechismus Japonensis.” - Japanese Journal of Religion Studies 40/2, 303-322.

Mungello, D. E. 1985. Curious Land: Jesuit Accomodation and the Origins of Sinology. Wiesbaden: Franz Steiner.

Ricci, M. 1985. Tianzhu shiyi (The True Meaning of the Lord of Heaven). Trans. Douglas Lancashire and Peter Hukuo-chen, S.J. St. Louis, Mo.: Institute of Jesuit Studies.

Rubiés, J.-P. 2005. "The Concept of Cultural Dialogue and the Jesuit Method of Accomodation between Idolatry and Civilization." - Archivum historicum societatis Iesu, 237-8.

Schütte, J. F. 1980-1985. Valignano's Mission Principles for Japan. 2 vols. St. Louis, Mo.: Institute for Jesuit Studies.

Standaert, N. 1980. Christianity and Cultures: Japan and China in Comparison 15431644. Ed. Antoni Üçerler. Rome: Jesuit Historical Institute.

Tacchi-Venturi, P. S.J. Le Opere Storiche del P. Matteo Ricci, S.J. 2 vols. Macerata: Gioigetti.

Valignano, A. S.J. 1944. Historia el Principio y Progresso de la Compañía de Jesús en las Indias Orientales. Ed. Josef Wicki. Rome: Jesuit Historical Institute.

Valignano, A. S.J. 1586. Catechismus Christianae fidei, in quo veritas nostrae religionis ostenditur \& sectae Japonenses. Olyssipone: A. Riberius.

Xavier, F. 1944-1945. Epistolae S. Francisci Xavierii aliaque eius scripta. 2 vols. Eds. Georg Schurhammer, S.J. and Josef Wicki, S.J. Rome: Jesuit Historical Institute.

Zürcher, E. 1962. Buddhism: Its Origin and Spread in Words, Maps, and Pictures. New York: St. Martin. 